\title{
HYPERBARIC OXYGENATION THERAPY FOR TREATING COMPLICATED COVID-19: FIRST EXPERIENCE
}

\author{
Mozgovoy ED', Udalov YuD², Ochkolias MV³
}

${ }^{1}$ FSUC "State scientific research institute for especially pure biospecimen" of the FMBA of Russia, Saint-Petersburg, Russia

${ }^{2}$ FSBI "Russian State Research Center — Burnasyan Federal Medical and Biophysical Center" of the FMBA of Russia, Moscow, Russia

${ }^{3} \mathrm{SBCl}$ LR "Clinical interdistrict hospital of Gatchina", Gatchina, Russia

Highly virulent SARS-CoV-2 emerged in Wuhan, China, and rapidly spread across the globe afflicting 14.5 million and killing over 600,000 people. The key factors affecting the severity of COVID-19 include advanced age and respiratory failure requiring mechanical ventilation (MV). Mortality rates estimated for mechanically ventilated patients with SARS-CoV-2-induced respiratory failure are $76.4 \%$ in the 18-65 age group and $97.2 \%$ in individuals over 65 years. At present, extracorporeal membrane oxygenation (ECMO) remains a life-saving method of choice. It is essentially a lung bypass system for direct oxygenation of the blood. It is an invasive and costly procedure performed only at specialized medical care facilities. China, USA, Germany, France and Israel have already launched large-scale research and clinical studies of non-invasive approaches to improving the efficacy of oxygen therapy in patients with complicated viral pneumonia, such as hyperbaric oxygen therapy (HBOT). HBOT is a well-established treatment for anaerobic and aerobic infections accompanied by soft tissue necrosis, carbon monoxide poisoning, stubborn wounds, including non-healing diabetic ulcers, complications of radiation therapy, stroke sequelae, brain injuries, decompression sickness, and other conditions. The use of HBTO in patients with viral infection, pulmonary edema and pneumonia is supported by the laws of physics and clinical/physiological effects in response to the exposure of elevated air pressure and hyperoxic environment. This review provides rationale for using hyperbaric oxygenation therapy in patients with SARS-CoV-2-induced viral pneumonia and presents the first data on the beneficial effects of HBTO in Chinese patients with COVID-19 complications.

Keywords: coronavirus, COVID-19, SARS-CoV-2, SARS-COV-2, hyperbaric oxygenation

Received: 28.06.2020 Accepted: 13.08.2020 Published online: 18.08.2020

DOI: $10.47183 /$ mes.2020.010

\section{ГИПЕРБАРИЧЕСКАЯ ОКСИГЕНАЦИЯ В ЛЕЧЕНИИ ОСЛОЖНЕННЫХ СЛУЧАЕВ COVID-19: ОБЗОР ПЕРВОГО ОПЫТА ПРИМЕНЕНИЯ}

\author{
Е. Д. Мозговой', Ю. Д. Удалов², М. В. Очколяс ${ }^{3}$
}

1 ФГУП «Государственный научно-исследовательский институт особо чистых биопрепаратов» ФМБА России, Санкт-Петербург, Россия 2 ФГБУ «Государственный научный центр Российской Федерации - Федеральный медицинский биофизический центр им. А. И. Бурназяна» ФМБА России, Москва, Россия

з ГБУз ЛО «Гатчинская клиническая межрайонная больница», Гатчина, Россия

\begin{abstract}
Высоковирулентный вирус SARS-CoV-2, впервые появившись в Ухане (Китай), быстро распространился по всему земному шару, поразил к настоящему времени более 14,5 миллионов человек и привел к смерти более 600 тысяч человек. Ключевыми критериями, влияющими на степень тяжести течения заболевания COVID-19, являются возраст пациента и развитие дыхательной недостаточности, требующей перевода пациента на искусственную вентиляцию легких (ИВЛ). Согласно опубликованным данным, смертность пациентов на ИВЛ при дыхательной недостаточности, вызванной вирусом SARS-CoV-2, составляет 76,4\% в возрастной группе 18-65 лет и 97,2\% в возрастной группе 65+ лет [1]. В настоящее время методом выбора спасения жизни при развивающейся дыхательной недостаточности является экстракорпоральная мембранная оксигенация (ЭКМО, «искусственное легкое»), заключающаяся в прямой оксигенации крови в обход пораженной легочной ткани. Данный метод является инвазивным, дорогостоящим и доступным только в клиниках специализированной медицинской помощи. В КНР, США, Германии, Франции, Израиле приступили к полномасштабным научным и клиническим исследованиям неинвазивных методов повышения эффективности кислородной поддержки пациентов при осложненном течении вирусной пневмонии, в первую очередь гипербарической оксигенации (ГБО) [2], которая является всемирно признанным методом лечения анаэробной и аэробной инфекций с некрозом мягких тканей, отравлений продуктами горения, хронических незаживающих ран, в том числе диабетических язв, осложнений лучевой терапии, последствий инсультов и травм головного мозга, декомпрессионной болезни и ряда других заболеваний и состояний [3]. Применение ГБО у пациентов с вирусной инфекцией, отеком легких и пневмонией, основано на знании законов физики и клинико-физиологических эффектов, возникающих в человеческом организме в ответ на одномоментное воздействие сразу двух факторов: повышенного давления и гипероксической среды. В настоящем обзоре приведено обоснование применения гипербарической оксигенации при вирусной пневмонии SARS-СoV-2 и первые сравнительные данные о положительном эффекте лечения ГБО в клинической практике в Китае при лечении осложненных форм заболевания новой коронавирусной инфекцией COVID-19.
\end{abstract}

Ключевые слова: коронавирус, SARS-CoV-2, COVID-19, SARS-COV-2, гипербарическая оксигенация

Статья получена: 28.06.2020 Статья принята к печати: 13.08.2020 Опубликована онлайн: 18.08.2020

DOI: $10.47183 /$ mes.2020.010

Highly virulent SARS-CoV-2 emerged in Wuhan, China, and rapidly spread across the globe afflicting 14.5 million and killing over 600,000 people.

Clinical presentations of the virus are varied, ranging from no symptoms to severe complications and life-threatening multiorgan failure. Factors predisposing to severe disease include advanced age and pre-existing conditions: elderly and comorbid patients are at a higher risk for severe acute respiratory symptom (SARS) and death. Another laboratory predictor of disease severity is elevated D-dimer, a product of fibrinogen degradation, indicating hypercoagulability $[4,5]$.

Progressive respiratory failure requiring mechanical ventilation (MV) is the most important prognostic factor of severe disease and death in patients with COVID-19. Mortality rates estimated 
for mechanically ventilated patients with SARS-CoV-2-induced respiratory failure are $76.4 \%$ in the 18-65 age group and $97.2 \%$ in individuals over 65 years $[1,6]$.

Extracorporeal membrane oxygenation (ECMO, also known as artificial lung technology) is a potentially life-saving alternative for patients with progressive respiratory failure. It is essentially a lung bypass system for direct oxygenation of the blood. It is an invasive and costly procedure performed only at specialized medical care facilities.

Hyperbaric oxygen therapy is becoming increasingly important now that there are more hospital admissions for moderate and severe forms of COVID-19. It is a highly effective non-invasive treatment that saves lives and, in most cases, eliminate the need for MV or ECMO [7].

\section{Physical and physiological principles of HBOT}

Hyperbaric oxygen therapy (HBOT) is a well-established treatment for anaerobic and aerobic infections accompanied by soft tissue necrosis, carbon monoxide poisoning, stubborn wounds, including non-healing diabetic ulcers, complications of radiation therapy, stroke sequelae, brain injuries, decompression sickness, etc. [3].

The idea of using HBOT in COVID-19 patients was neither random nor empirical. The rationale for HBOT is supported by universal gas laws and specifically by Dalton-Henry's law. A patient placed into a hyperbaric oxygen chamber breathes a high-pressure gas mixture enriched in oxygen. This increases the amount of oxygen dissolved in tissue. Oxygen uptake and binding by hemoglobin depends on the diffusion of dissolved oxygen across the alveolar or capillary wall into the blood plasma and across the red cell membrane to hemoglobin. Reduced diffusion of oxygen molecules results in falling blood oxygenation.

A standard mask oxygen therapy is ineffective in patients with virus-induced pulmonary interstitial edema and progressive respiratory failure since it cannot modulate gas pressure in alveoli and therefore cannot compensate for oxygen deprivation or dampen pulmonary and systemic inflammation. According to Dalton-Henry's law, HBOT should improve oxygenation by increasing the rate of oxygen diffusion in the lungs, oxygen solubility in the blood plasma, oxygen uptake by hemoglobin and oxygen delivery to hypoxic tissue by microvessels, thereby reducing or eliminating oxygen debt [3].

For a clinician, the clinical outcomes of a treatment are more important than the physical principles behind it. Firstly, HBOT improves oxygen saturation in tissue and reverses hypoxia (most importantly in the central nervous system) caused by pulmonary inflammation. Secondly, HBOT has a metabolic effect consisting in the stimulation of glucose breakdown and elevation of the levels of macroergic compounds, which creates sufficient potential for better endurance and therefore makes it possible to proceed to physical therapy in shorter time. Thirdly, HBOT stimulates epithelization and functional angiogenesis of capillaries and reduces the risk for thrombotic complications by promoting platelet disaggregation and exerting a heparin-like effect on the coagulation system. HBOT also has a vasopressor effect, resulting in edema resolution. Finally, HBOT enhances the effects of antiviral and antimicrobial therapies and reduces their side effects [3].

At cellular and molecular levels, increased hydrostatic pressure and hyperoxia from HBOT epigenetically modulate the expression of human protein-coding genes. HBOT stimulates expression of genes involved in growth regulation, cell repair, production of cellular mediators and anti-inflammatory factors. It also suppresses genes involved in the production of proinflammatory factors and apoptosis. For example, high levels of tissue dissolved oxygen have an antiviral effect consisting in the increased production of reactive oxygen species [8] and hypoxia inducible factor (HIF), which, in turn, stimulates synthesis of antiviral peptides (defensins, cathelicidins) and suppresses secretion of proinflammatory cytokines, including IL-6 implicated in the cytokine storm [7, 9, 10].

Multiple studies have shown that HBOT has a prolonged systemic effect on the pathophysiology of various conditions, including acute pulmonary inflammation, impaired tissue perfusion, severe acute respiratory distress syndrome, and heart failure sequelae $[3,11,12]$.

Thus, HBOT, which is based on the principles of physiology and exploits the laws of physics for increasing diffusion and solubility of oxygen in the blood, might be an effective noninvasive alternative to ECMO in patients with COVID-19induced pneumonia.

\section{HBOT in managing COVID-19 complications: China's experience}

In April 2020, the Wuhan Yangtze River Shipping General Hospital, China, published 2 articles on the clinical application of HBOT in patients with COVID-19-induced pneumonia.

The article describes 5 clinical cases of severe and critical disease in patients with CT-confirmed bilateral pneumonia and failing standard oxygen support (without intubation). Prior to HBOT, all patients had been receiving standard mask oxygen therapy (average $\mathrm{SatO}_{2}=70 \%$ ).

HBOT was delivered at 1.6 ATA (in one case, the pressure was 2 ATA); the first session lasted for 90 min, the rest were 60 min long [13]. After each session, $\mathrm{SatO}_{2}$ values were growing until the following morning in all patients. The 24-h SatO2 monitoring showed that oxygen saturation reached its minimum at 8 am and demonstrated a steady positive dynamic after the beginning of therapy.

Clinical improvement (fever resolution, normal respiration rate, cough relief) and better results of laboratory tests for arterial blood gases, fibrinogen and D-dimer levels were observed after 3 to 8 HBOT sessions. The mean SatO2 value was growing steadily every day $(p<0.01)$; the mean daily SatO2 after an HBOT session exceeded 95\%. When the treatment was completed, the patients had a chest CT scan, which also showed improvement; later, the patients were discharged [13, 14].

The authors of the article provided additional consolidated data on 29 patients with milder forms of COVID-19 who had undergone HBOT and achieved similar results [14].

The significance of the foregoing case reports is supported by historical facts. The medical personnel in Wuhan reproduced the experiment conducted by Dr. Cunningham in a KansasCity clinic (MI, USA) in 1918 during the pandemic of Spanish influenza. Cunningham used a similar HBOT regimen (air pressure of 1.6 ATA, the same number of sessions) in an agonizing patient with severe respiratory failure [15]. The treatment brought immediate relief to his patient, just like in the reports of Chinese physicians.

\section{International clinical trials of HBOT for COVID-19}

Clinical trials of hyperbaric oxygenation and protocol development for this type of therapy have been already launched in US, Germany, France, and Israel in collaboration with other countries [2]. Among the trials registered at the National Library of Medicine of the National Institutes of Health 
Table. The list of actively recruiting clinical studies of the efficacy of hyperbaric oxygenation in the therapy of COVID-19 by National Institutes of Health, USA.

\begin{tabular}{|c|c|c|c|}
\hline & Medical facility, city (state), country & Number of participants & ClinicalTrials.gov ID \\
\hline 1. & NYU Winthrop Hospital (New-York, USA) & 40 & NCT04332081 \\
\hline 2. & Ochsner Medical Center, (Louisiana, USA) & NCT04343183 \\
\hline 3. & $\begin{array}{c}\text { White River Wound Healing Center (Arkansas, USA), Community Hospital (California, USA), } \\
\text { Innovative Healing Systems (Florida, USA), Decatur Memorial Hospital (Indiana, USA), } \\
\text { Providence Medical Wound Care Center (Kansas, USA), West Jefferson Medical Center } \\
\text { (Louisiana, USA), Ascension Providence Rochester Hospital Wound Care Center (Michigan, } \\
\text { USA), CHI Health Center (Tennessee, USA), Klinika Baromedical (Poznan, Poland) }\end{array}$ & 100 & NCT04386265 \\
\hline 4. & Sainte Anne Military Teaching Hospital (Toulon, France) & 100 & NCT04344431 \\
\hline 5. & Shamir Medical Center (Zerifin, Israel) & 30 & NCT04358926 \\
\hline 6. & $\begin{array}{c}\text { Bergmannsheil und Kinderklinik Buer GmbH (Gelsenkirchen, Germany), Krankenhaus St. } \\
\text { Joesf (Regensburg, Germany), Blekingesjukhuset (Karlskrona, Sweden), Karolinska Institutet } \\
\text { (Stockholm, Sweden), University of California (California, USA) }\end{array}$ & 200 & NCT04327505 \\
\hline
\end{tabular}

(USA; see Table), there are 6 ongoing studies, of which 2 are international multicenter trials.

Importantly, information on the clinical trials conducted by countries not listed in the NLM registry is available only at WHO's International Clinical Trials Registry Platform [16]; the platform allows conducting a detailed search in national registries. For example, the Chinese Clinical Trial registry has published information about the trial of HBOT for treating COVID-19induced pneumonia (ID ChiCTR2000032011) conducted by the Sixth Medical Center of PLA General Hospital (Beijing, China); the trial is now recruiting 45 patients [17].

Unfortunately, the Russian medical science has lost is leadership in hyperbaric medicine over the recent decades. The managerial approach to public health has caused stagnation in this field of research. Lack of clinical and research facilities for basic and applied research has forced many Russian specialists to take guidance in the data provide by their foreign colleagues.

In light of this, the first reports of positive clinical effects of HBOT observed in patients with severe COVID-19 receiving medical care in the ICU of Sklifosovsky Research Institute of Emergency Care and Burnazyan Federal Medical and Biophysical Center of FMBA, Russia, in June 2020, pose a significant value [18].

The data published by Burnazyan Federal Medical and Biophysical Center demonstrate a remarkable beneficial effect of HBOT sessions conducted as part of the combination therapy for patients with mild and severe COVID-19. After the very first session, there was a considerable improvement in patient condition manifested as a significant increase in oxygen saturation in the capillary blood. HBOT mitigates hypoxia and positively affects patient condition before the administered medication therapy can have its effect, stabilizes blood gas composition and helps to avoid mechanical ventilation in some cases, which is, undoubtedly, a considerable treatment success. The obtained clinical data encouraged the authors to recommend hyperbaric oxygenation as part of the combination therapy outlined in the interim guidance of the Russian Ministry of Healthcare [19].

\section{Some aspects of using HBOT in COVID-19 patients}

There should be strict adherence to safety and infection control measures aimed at preventing cross-contamination in hospital areas designated for COVID-19 patients and inside hyperbaric chambers. In Wuhan, patients flows arriving for the procedure and leaving the "red" zone were separated; hyperbaric chambers, other equipment and ventilation/gas exhaust systems underwent disinfection on a regular basis. None of the healthcare workers delivering HBOT to 35 COVID-19 patients contracted the infection; by contrast, cross-contamination rates reported by other hospital units were significant. Adherence to infection control and prevention measures is critical; otherwise, a hyperbaric chamber can become the source of contamination for both medical personnel and patients.

The majority of Russian clinics are equipped with monoplace hyperbaric chambers. This allows medical personnel to implement a personalized approach to treatment and disinfection. The patient can remain in the prone position for the entire session length. Prone positioning ensures good pulmonary blood flow, complete lung expansion and improved ventilation of areas that would be hypoventilated in a patient lying in the supine position.

HBOT technique used in patients with COVID-19 does not differ from a regular HBOT technique. Patients are eligible for this treatment if they do not have contraindications, their hemodynamics are stable and they breathe unassisted. The respiratory rate, blood pressure and SatO2 must be monitored before, during and after the session in order to ensure there is no oxygen overdose and to prevent oxygen poisoning.

\section{CONCLUSION}

There is first encouraging evidence of using hyperbaric oxygen therapy for treating life-threatening complications of the novel coronavirus infection. Many healthcare facilities have already launched large-scale clinical and research studies to investigate the potential of hyperbaric oxygen therapy $[2,13,14,18]$.

As part of a combination therapy for the complications of viral pneumonia, HBOT prevents critical hypoxemia and thereby eliminates the need for mechanical ventilation.

Provided by Russian and international teams, research and clinical data on using HBOT in patients with pneumonia and respiratory failure caused by COVID-19 are crucial for reintroducing this method into clinical practice and employing it for managing patients with SARS-CoV-2 or other viral infections. 


\section{References}

1. Richardson S. Presenting Characteristics, Comorbidities, and Outcomes Among 5700 Patients Hospitalized With COVID-19 in the New York City Area. // Journal of American Medical Association, 2020 Apr 22; [Epub ahead of print, e206775].

2. Https://clinicaltrials.gov/ct2/results?cond=hyperbaric+oxygen $+\mathrm{c}$ ovid [20.07.2020].

3. Jain KK. Textbook of Hyperbaric Medicine. $6^{\text {th }}$ ed. Cham, Switzerland: Springer. 2017.

4. Zhou F et al. Clinical course and risk factors for mortality of adult inpatients with COVID-19 in Wuhan, China: a retrospective study. // Lancet 2020; 395(10229):1054-1062.

5. Huang $\mathrm{C}$ et al. Clinical features of patients infected with 2019 novel coronavirus in Wuhan, China. // Lancet 2020; 395(10223):497506.

6. Yang $X$ et al. Clinical course and outcomes of critically ill patients with SARS-CoV-2 pneumonia in Wuhan, China: a single-centered retrospective, observational study. // Lancet Respiratory Medicine 2020; [Epub ahead of print]

7. Thibodeaux $\mathrm{K}$ et al. Hyperbaric oxygen therapy in preventing mechanical ventilation in COVID-19 patients: a retrospective case series. // Journal of wound care. 2020 May 1;29(Sup5a):S4-S8.

8. Baugh MA. HIV: reactive oxygen species, enveloped viruses and hyperbaric oxygen. // Medical hypotheses, 2000; 55(3):232-238.

9. Thom SR. Hyperbaric oxygen: its mechanisms and efficacy. // Plastic and reconstructive surgery, 2011; 127(Supp 1):131S-141S

10. Weisz G et al. Modification of in Vivo and in Vitro TNF-alpha, IL-1, and IL-6 Secretion by Circulating Monocytes During Hyperbaric

\section{Литература}

1. Richardson S. Presenting Characteristics, Comorbidities, and Outcomes Among 5700 Patients Hospitalized With COVID-19 in the New York City Area. // Journal of American Medical Association, 2020 Apr 22; [Epub ahead of print, e206775].

2. Https://clinicaltrials.gov/ct2/results?cond=hyperbaric+oxygen+c ovid [20.07.2020].

3. Jain KK. Textbook of Hyperbaric Medicine. $6^{\text {th }}$ ed. Cham, Switzerland: Springer. 2017.

4. Zhou F et al. Clinical course and risk factors for mortality of adult inpatients with COVID-19 in Wuhan, China: a retrospective study. // Lancet 2020; 395(10229):1054-1062.

5. Huang $\mathrm{C}$ et al. Clinical features of patients infected with 2019 nove coronavirus in Wuhan, China. // Lancet 2020; 395(10223):497506.

6. Yang $X$ et al. Clinical course and outcomes of critically ill patients with SARS-CoV-2 pneumonia in Wuhan, China: a single-centered, retrospective, observational study. // Lancet Respiratory Medicine 2020; [Epub ahead of print].

7. Thibodeaux $\mathrm{K}$ et al. Hyperbaric oxygen therapy in preventing mechanical ventilation in COVID-19 patients: a retrospective case series. // Journal of wound care. 2020 May 1;29(Sup5a):S4-S8.

8. Baugh MA. HIV: reactive oxygen species, enveloped viruses and hyperbaric oxygen. // Medical hypotheses, 2000; 55(3):232-238.

9. Thom SR. Hyperbaric oxygen: its mechanisms and efficacy. // Plastic and reconstructive surgery, 2011; 127(Suppl 1):131S-141S

10. Weisz $\mathrm{G}$ et al. Modification of in Vivo and in Vitro TNF-alpha, IL-1, and IL-6 Secretion by Circulating Monocytes During Hyperbaric
Oxygen Treatment in Patients With Perianal Crohn's Disease. // Journal of clinical immunology, 1997 March; 17(2):154-9.

11. Sevtap Hekimoglu Sahin. The effect of hyperbaric oxygen treatment on aspiration pneumonia. // Journal of molecular histology, 2011; 42:301-310.

12. Rogatsky GG et al. Acute respiratory distress syndrome in patients after blunt thoracic trauma: the influence of hyperbaric oxygen therapy. // Advances in experimental medicine and biology. 2003;540:77-85

13. Zhong $X$ et al. Effect of hyperbaric oxygen therapy on hypoxia in patients with severe new coronavirus pneumonia: first report. // Chinese Journal of Marine Medicine and Hyperbaric Medicine. 2020.

14. Harch PG. Hyperbaric oxygen treatment of novel coronavirus (COVID-19) respiratory failure. // Medical Gas Research [Epub ahead of print, 2020 May 23].

15. Sellers LM. The fallibility of the forrestian principle «semper primus pervenio maxima cum VI». // Laryngoscope. 1964; 74:613-633.

16. Https://www.who.int/ictrp/ru/ [20.07.2020].

17. Http://www.chictr.org.cn/showprojen.aspx?proj=52142 [20.07.2020]

18. Samoilov A.S., Udalov Y.D., Sheyanov M.V., Gholinsky A.V., Litvinenko A.B. Experience in Applying Hyperbaric Oxygen Therapy Using Portable Pressure Chambers for the Treatment of Patients with the Novel Coronavirus Infection COVID-19. Journal Biomed. 2020;(2):39-46. (In Russian).

19. [Temporary guidelines of the Ministry of health of the Russian Federation "Prevention, diagnosis and treatment of new coronavirus infection (COVID-19)"]. Version 6 (28.04.2020).

Oxygen Treatment in Patients With Perianal Crohn's Disease. // Journal of clinical immunology, 1997 March; 17(2):154-9.

11. Sevtap Hekimoglu Sahin. The effect of hyperbaric oxygen treatment on aspiration pneumonia. // Journal of molecular histology, 2011; 42:301-310.

12. Rogatsky $G G$ et al. Acute respiratory distress syndrome in patients after blunt thoracic trauma: the influence of hyperbaric oxygen therapy. // Advances in experimental medicine and biology. 2003;540:77-85.

13. Zhong $X$ et al. Effect of hyperbaric oxygen therapy on hypoxia in patients with severe new coronavirus pneumonia: first report. // Chinese Journal of Marine Medicine and Hyperbaric Medicine. 2020.

14. Harch PG. Hyperbaric oxygen treatment of novel coronavirus (COVID-19) respiratory failure. // Medical Gas Research [Epub ahead of print, 2020 May 23].

15. Sellers LM. The fallibility of the forrestian principle «semper primus pervenio maxima cum V|». // Laryngoscope. 1964; 74:613-633.

16. Https://www.who.int/ictrp/ru/ [20.07.2020].

17. Http://www.chictr.org.cn/showprojen.aspx?proj=52142 [20.07.2020]

18. Самойлов А.С., Удалов Ю.Д., Шеянов М.В., Жолинский А.В., Литвиненко А.Б. Опыт применения гипербарической оксигенотерапии с использованием портативных барокамер для лечения пациентов с новой коронавирусной инфекцией COVID-19. // Биомедицина. 2020; (2):39-46.

19. Временные методические рекомендации Минздрава России «Профилактика, диагностика и лечение новой коронавирусной инсекции (COVID-19)». // Версия 6 (28.04.2020). 